\title{
Revenge and Retribution: Reli(E)Ving Trauma in Frozen by Bryony Lavery
}

\author{
Kamelia Talebian Sedehi (Corrospnding author) \\ English Department, Faculty of Modern Languages and Communication, Universiti Putra Malaysia, Malaysia \\ Tay Lai Kit \\ English Department, Faculty of Modern Languages and Communication, Universiti Putra Malaysia, Malaysia \\ Wan Roselezam Wan Yahya \\ English Department, Faculty of Modern Languages and Communication, Universiti Putra Malaysia, Malaysia
}

Received: 15-08-2016

doi:10.7575/aiac.ijclts.v.4n.4p.1
Accepted: 12-09-2016

Published: 31-10-2016

\begin{abstract}
Widely studied and defined, trauma has made its way into the streamline of various disciplines of study. Events such as war, natural disasters, violence, and verbal degradation are some factors which could traumatize a person. Although there is no definitive symptom for trauma, one usually suffers from social anxiety, low self-esteem, erratic behavior, or even aggressive tendency. In this article, we attempt to trace the psyche of the protagonist Ralph, in Bryony Lavery's play Frozen. We want to identify the cause and effect of his traumatic experience during childhood when he was victimized sexually by his mother's multiple lovers. In addition, the article will also shed light on his view of female figures in general as he grows into his adulthood. We argue that Ralph is stuck in his past and is constantly seeking for opportunities to create and relive the experience which has shaped him into becoming the "monster" he is now. Much to his dismay, we will see how his effort in exacting revenge on his mother is futile and that his thought of retribution to relieve himself winds up in death.
\end{abstract}

Keywords: Child Abuse, Sexual Abuse, Trauma, Victim

\section{Introduction}

Trauma happens when people experience situations which affect their mentality. These intolerable plights are the main cause of the ill condition. Drawing its original meaning from Greek word; wound, trauma indicates that a person who is traumatized must have suffered a particular extreme incident in his/her life before. To further specify, The Diagnostic and Statistical Manual of Mental Disorders, 4th edition, Text Revision (DSM-IV-TR; American Psychiatric Association [APA], 2000) defines a trauma as "direct personal experience of an event that involves actual or threatened death or serious injury, or other threat to one's physical integrity; or witnessing an event that involves death, injury, or a threat to the physical integrity of another person; or learning about unexpected or violent death, serious harm, or threat of death or injury experienced by a family member or other close associate (Criterion A1). The person's response to the event must involve intense fear, helplessness, or horror (or in children, the response must involve disorganized or agitated behavior) (Criterion A2)." (463)

Therefore, the traumatized subject undergoes various extreme situations which lead him to horror, helplessness and fear. Based on Collins here are two kinds of traumatic events,

Some traumatic events are short- term- single, relatively brief but extreme threats like rape, assault, or a natural disaster. Others are long- term events that occur over time and result in prolonged or repeated exposure to the extreme threat. Examples of the latter include childhood sexual abuse, domestic violence and some technological disasters. (Collins, 5)

Situations like war, verbal degradation, natural disasters, and mass interpersonal violence are some of the events which could traumatize an individual. Moreover, "According to Kali Tal (1996), the subject has to - tell and retell the story of the traumatic experience, to make it - real\| both to the victim and to the community\| (p. 21). Also philosophers have considered how, under the influence of trauma, memories and perceptions have become suspended: - No trace of a registration of any kind is left in the psyche, instead, a void, a hole is found"(Babaee \& Wan Yahya 1826).Even in case of rape, the victim "cannot express her feeling within language, she prefers to keep silent" (Talif \&Sedehi 623). When a person is traumatized, there is a part of him that is stuck in the past within the exact experience and therefore affects his consciousness every now and then. All the same, a child psychiatrist also states that, "psychic trauma occurs when sudden unexpected, overwhelming intense emotional blow or a series of blows assaults the person from outside. Traumatic events are external, but they quickly become incorporated into the mind" (Terr1990, p. 8). It is difficult treat, let alone cure, as it is a subjective experience to different traumatic subjects. Some have relapse of repetitive 
nightmares; some exhibit wild behaviors; others may require a specific context of situation in order for the trauma to be instigated. However, it needs to be clarified that there is no definitive symptoms for trauma as the experience varies (Grayson 3). As such, psychologists have different ways in dealing with distinctly traumatizing experience - writers may be encouraged to write, artists to dwell in the realm of art, musicians to compose music.

However, the present study will focus on trauma which results from victimization of child sexual abuse. "Child abuse and neglect are defined by the federal Child Abuse Prevention and Treatment Act (CAPTA) which was first enacted in 1974" (Collins 364). Based on this article, some of the abuses that children undergo by their parents, relative or total strangers were explained. In the 1970 and 1980s many authors wrote about children sexual abuse and the followed each other in rapid succession (Gold 4). We have selected a play by Bryony Lavery, Frozen (1998) as the core text for this paper, centering on the traumatized psyche of the protagonist, Ralph. The article intends to highlight the cause and effect of sexual abuse which took place in him. Further, we will also look into his behavioral characteristics in terms of dealing with female characters and how his traumatic sexual encounter during young childhood affects his judgment, thoughts, and actions now in his adulthood. To begin, it has been reported in several fields of study, usually clinical and psychological, that childhood abuse is often associated with trauma in which they suffer later on in adulthood (e.g., Briere \& Runtz, 1988, 1990; Gross \& Keller, 1992; Hoglund \& Nicholas, 1995). Child abuse happens when the child is not ready mentally and physically for any kind of sexual encounter. These children are victims of molestation, rape, incest, intercourse, oral sex or any other kind of abuse. However, most of them do not report the incident as they consider it as an experience which questions their self-worth and confidence. Instead, they choose to repress and hideaway that piece of information to themselves as to mask the pain, embarrassment, and humiliation. Little do they know that all these harboring of negative feelings will culminate psychological and physiological problems within them. Victims of child sexual abuse will usually exhibit several peculiar symptoms such as depression, suicidal tendency, low self-esteem, or inferiority complex. These children will not be able to communicate with others as the abuse made their world unsafe (Wieland9 2). These are examples of those who "prefer" to suffer in silence and go on repressing the unresolved issue. However, there are also cases where victims are so affected that they are molded into a more insensitive and aggressive being; such as Ralph, the protagonist of the text. As the children are abused sexually, the abuse shapes "the way a child perceives events, forecasts the future, and constructs his plans" (Wieland 2). This then explains the title of our paper - due to his tainted past, Ralph now seeks revenge and retribution through abducting and killing young innocent girls. To relate this to what has been said earlier, he is hung up on his own traumatic event and tries to relive that moment every now and then whenever opportunity presents itself. By reliving it, he could, at least in his own judgment, relieve himself from the dark past and move on as a normal being.

\section{Trauma in Frozen}

As Frozen starts, the reader perceives that Nancy is looking for her daughter, Rhona, who has" (...) been missing for five years" (20) at the age of ten. She searched everywhere all those years to find her daughter but her effort is to no avail. Years later, the police arrested Ralph as they found out that he molested, killed, and then buried the young girls. "We have apprehended a man in the unsuccessful attempted abduction of a young girl... subsequent inquiries have uncovered a lock- up shed the earth floor contains the remains of other children the man is now giving us names" (26). Ralph kidnapped these girls, abused them sexually and murdered them. In fact, "research has indicated that children who have been sexually abused experience depression, suicidal ideation and revictimization significantly more often than" other children and here Ralph is not an exception (Wieland 3). Imprisoned, Ralph finds himself talking to a criminal psychologist, Agnetha, who occasionally visits him in the interest of immersing and dwelling in his psychotic mind. As the conversation between Agnetha and Ralph draws on in the conjugal visit room, he thinks that she has taken an interest in him. He did not think or defend himself about the murders which he has committed. "I think she quite liked me oh yes she was interested" (11). He does not understand the gravity of his deeds to those girls and their respective families. In fact, he videotaped all the girls he abused and labeled the tapes with titles such as "Lollitots, Lesbian Lolita, little Red Riding Hood" (16). His act shows that he is not conscious of what he did to the girls and seems to think that the girls are the ones responsible for flirting and initiating sexual affair with him. As a result, Ralph "is currently in Long Larton Maximum Security Prison serving a life sentence without remission for the abduction, sexual assault and murder of seven young girls over a period of twenty- one years" (33).

However, there are always more than meets the eyes. Reading between the lines, it is important to highlight the cause which leads Ralph in shaping himself into becoming the serial killer that he is in the play. As it turns out, Ralph was a victim of child abuses to his mother and her many "lovers". There was a time when he fell down on his penis and it worsens the damage because of the prior damage in penis. In his own words, "[i]t was serious because it was same place as where my mam threw me in the sink" (44). His mother did not take care of him as she should. She did not protect him from all the men. Though she was sad "she could get away with it still!" (44).Through his narration, we can see how his mother had not been the best role model or guardian in his life. Her mistreatment towards him has instilled trauma and repressed anger in him that he becomes the "monster" that he is now. Agnetha knows that Ralph was sexually abused and now she is reporting the case, in which children are sexually abused; as a result, they retaliate by exerting cruel actions unto others. "Doctor Nabkus and I observed a group of toddlers over three months... half of whom had been subjected to serious physical abuse half of whom had not we were interested in how the toddlers responded to a classmate in distress" (46-47). The same as these children treat each other harshly as they were subject of molestation, Ralph also mistreated and abused girls as he was traumatized when he was a child too. He is ready to rape the girls as when he was a child he was raped too. "You put your chair very close in to the table. You open your legs as wide as they'll go. Then I put my hand slowly down so Chummy over there" (48). No matter what position the 
girl or woman has, he just intends to rape her. As Ralph addresses Agnetha and talks about sex, Agnetha explains what trauma does to the mentality of sexually abused children. In general, "Sexual abuse is intrusive. It intrudes on a child's physical body, sexual developments and sense of self. This intrusion is experienced both emotionally and physically and for older children cognitively as well" (Wieland 8). As such Agnetha continues that children sexual abuse causes "profound and pathological changes in the structure of the brain as surely as does physical injury" (48). She informs that when the same traumatic event or similar events take place, the person will react to it time and again as he could not handle it properly and get rid of it.

Furthermore, Agnetha explains how of sexually abused children is damaged. "Abuse also affects the relationship between the left hemisphere of the brain... which plays a large role in logic and language and the right hemisphere, which is thought to play a disproportionately large role in creativity and expression" (49). As Agnetha explains all the information, Ralph is thinking about her. He thinks that she is in love with "she was consulting with me obviously of yes oh yes" (49). His right hemisphere is damaged as a result of abuse; therefore, he cannot think properly. He lost his reason and his language is repetitive which was indicated in the repetition of "oh yes (49).

In addition, these abused children "do not have a compass" (50). Their sense of morality is damaged; therefore, they do not have any sense of remorse or guilt. These victims "literally lack some brain organizations that allow them to make strong connections to other human beings" (50). As such, he cannot communicate and connect with other people on a deeper emotional level, such as love or hatred. He was victimized before; therefore, his mind is programmed as such that he does not trust anybody. As mentioned before, the sexually traumatized children lose their sense of morality and they do not regret their wrong action. Ralph is bewildered with the idea of remorse; he says, "[r]emorse. What is that... remorse? "(60). He does not regret the fact that he abused girls and killed them. Agnetha asks Ralph about his childhood and he describes it as "steakmasters...oven cook chips...viennettas... after dinner mints... hamlet cigars... crusty warm bread. HaagenDazs ice cream any many flavors... mixed grills" (61- 62). However, that is not the truth; he only projects the warm images to hide the ugly truth. Therefore, Agnetha confronts him with his reality. "Your mom pops you in the sink step dads arrive you get chased you get fucked up your little bottom, don't you? Up your sad, dirty little ass" (62). The mother is disloyal, sexually promiscuous, and has no regards to her son's welfare. To worsen the situation, the mother constantly brought home different men to bed - this definitely taints his image of women and his perceptions toward them. Driver and Droisen note that "[m]ajority of abuse is committed by men who know the child, especially fathers or stepfathers" (198917), here Ralph is victim of his stepfathers. Therefore, he generally sees female figures as female sexual organs. Even at the beginning of the play, Ralph addresses the criminal psychologist, Agnetha as a female sexual organ. In his adulthood, he raped the girls as he thought that they enjoyed it. Addressing these girls as Lolitta refers back to the disloyal nature of Lolitta. As he thinks that these girls enjoyed being raped, he says that he does not think he hurts Nancy's daughter. He just recognized that he hurts all those girls by raping them when he remembers the past when the stepfathers abused him. "I'll make sure you hear what I say.... Stand still stand still stand still you stand still and don't move one muscle not one you don't even blink, twat until I know you know I mean what I say. See it in my eyes, twat?" (70). As he remembers those incidents "Dry painful sobs start. Awful, embarrassing, rusty crying... he holds his chest in pain as he subsides" (71). Some of the features of trauma are the intense terror, horror or helplessness (Colten and Mannarino 3) and here Raphael remembers his helplessness in the hands of his stepfathers and his fear of them.

Sexual abuse affects children's mentality and physicality so much that even after many years the victim feels its pain. Now that Ralph perceived his wrong actions he starts saying sorry to people who were hurt by him. "Dear Mrs. Shirley... Dear Nancy... Dear Mrs. Shirley... I am writing to you... I am sorry... I am very sorry... I am sorry... I am sorry that I murdered... I am sorry that I abused... I am sorry that i..." (71). He realizes that he hurt those girls and their families. Here, Ralph is suffering from psychological and physical memories and he should unburden them (Sedehi a Talif 56). Ralph is so traumatized by raping that in every sentence he says, he uses this word "Fucking shite! Fucking quack cunt!... fucking wrong" (74). Now that he perceived the reality and the pain he imposed on those girls and their families, he has physical pain which leads him to think that he has cancer and this pain "fucking hurt" (75). He showed violence toward women as it was considered as something natural for him (Yahya, Rahman, \& Zainal 25); however, he was wrong. In fact, he has conscientious pain which causes physical pain. Finally as he could not tolerate this guilt he commits suicide.

\section{Conclusion}

On the surface level, trauma can be seen as a highly objective experience where one can almost identify the meaning upon seeing or hearing it. It is extremely common when people conjure up images of traumatized victims with unstable mind, anxious outlook, and miserable social angst. Albeit all that has been mentioned, trauma is a subjective experience and varies to different people. The protagonist, Ralph in this paper is affected in a way that he needs an outlet to relieve his own traumatic experience. By putting all the evidences in the play together, it is evident that his mentality is deeply scarred by his mother - if he considers her as one. Her promiscuous lifestyle with different men who constantly abuse him as well as her lack of maternal care have rendered him into an emotionless state of mind, in which he carries into his adulthood. Before long, the psyche within him has been shaped, molded, programmed itself to that of a serial killer; one who does not feel remorse nor does he have the ability to love others. He has no control over his relapse of desire to rape and murder the girls. In his mind, it is most likely that he views all females are 'cunts', that they all share the same promiscuity trait as his mother does. This thoroughly justifies his decision on labeling the videotapes with degrading female icon, Lolita. Ultimately, Ralph tries to redeem his tainted childhood by constantly re-creating and reliving the 
moment in which he cannot seem to get pass with. Alas, it is a cruel cyclical motion that he relentlessly seek because he relieves himself of the tainted past for every girl he victimized temporarily. As a result of his failed attempt in revenge and retribution for his innocence, he decided to commit suicide in the jail in the end. Trauma, in his case, is the end to his beginning.

\section{References}

Babaee, R. and Wan R. Wan Y. (2014). Salinger's Depiction of Trauma in The Catcher in The Rye. Theory and Practice in Language Studies, 4(9). pp. 1825-1828

Briere, J., \& Runtz, M. (1988). Multivariate Correlates of Childhood Psychological and Physical Maltreatment Among University Women. Child Abuse \& Neglect, 12, 331-341.

Briere, J., \&Runtz, M. (1990). Differential Adult Symptomatology Associated with Three Types of Child Abuse Histories. Child Abuse \& Neglect, 14, 357-364.

Collins, B. G. and Thomas M. Collins.(2005). Crisis and Trauma, Developmental- Ecological Intervention. New York: Lahaska Press.

Colten, J. A. and Anthony P. M.(2006). Treating Trauma and Traumatic Grief in Children and Adolescents. New York: Guilford Press.

Driver, E. and Audrey, D. (1989). Child Sexual Abuse, Feminist Perspective. London: Macmillan.

Gold, S. N. (2000).Not Trauma Alone, Therapy for Child Abuse Survivors in Family and Social Context. New York: Brunner-Routledge.

Grayson, J.(2012). "Evidence-based Treatments for Childhood Trauma."Virginia Child Protection Newsletter, 95, 1-20. Web. 20 Oct. 2015. <http://psychweb.cisat.jmu.edu/graysojh/pdfs/Volume95.pdf>.

Gross, A. B., \& Keller, H. R. (1992). Long-term Consequences of Childhood Physical and Psychological Maltreatment.Aggressive Behavior, 18.pp. 171-185.

Hoglund, C. L., \& Nicholas, K. B. (1995). Shame, Guilt, and Anger in College Students Exposed to Abusive Family Environments. Journal of Family Violence, 10, 141-157.

Lavery, B. (2002).Frozen.New York: Dramatist Play Service Inc.

Sedehi, K., T. and Talif, R. (2014). "Speaking Characters in Possessing Secret of Joy". 3L; Language, Linguistics and Literature, The Southeast Asian Journal of English Language Studies, 20 (2). pp. 55- 66.

Talif, R. and Sedehi, T. K. (2014). Pertanika Journal of Social Sciences and Humanities, 22(2). pp. $621-631$.

Terr, L. (1990). Too Scared to Cry: Psychic Trauma in Childhood. New York: Harper \& Row.

The Diagnostic and Statistical Manual of Mental Disorders, 4th edition, Text Revision (DSM-IV-TR; American Psychiatric Association [APA], 2000)

Wieland, S. (1998). Techniques and Issues in Abuse-Focused Therapy with Children and Adolescents Addressing the Internal Trauma. California: Sage Publication.

Yahya, W. R, Rahman, E. A. and Zainal, Z. I. (2010). Male Gaze, Pornography and the Fetishised Female. International Journal of Interdisciplinary Social Sciences, 5(1). pp. 25- 38. 